\title{
Z HISTORII ZAGRANICZNEGO RUCHU TURYSTYCZNEGO W POLSCE
}

\author{
PIOTR KŁYSZ \\ Instytut Paleogeografii i Geoekologii, Zakład Geomorfologii, \\ Uniwersytet im. Adama Mickiewicza
}

\begin{abstract}
The beginnings of tourist traffic in Poland go back to the second half of the 20th century. Earlier, particularly between 1945-1856, foreign tourism was almost non-existent. Tourism started to develop at the end of that period. The development gained momentum in the first half of the 1960s. In 1955 about 77,000 foreign tourists came to Poland and 44,000 Poles went to other countries. These figures have been growing considerably in the following years - in 1965 778,400 Polish tourists visited other countries and as many as $1,162,900$ foreign tourists came to Poland.

Foreign tourist traffic has been mainly organized by the Polish Travel Office Orbis. Other institutions involved in the organization of foreign tourism in Poland included PTTK (Polish Tourist and Sightseeing Organization), ZMS (Union of Socialist Youth), ZSP (Union of Polish Students), Polish Tourist Cooperative Gromada, and Turysta Cooperative.

The opinions about Poland's attractiveness for tourists varied. In the 1980s many foreign tourists believed that Poland is not a very attractive tourist destination.

A number of people who visited Poland in recent years have had a completely different opinion. In tourist materials dating back to the beginnings of the 1960s we can read that foreigners find in Poland everything that could be expected from a tourist trip, i.e., beautiful landscapes (Photo 1), and beautiful historical architecture (Photo 2).

Polish tourists also go to many attractive regions of the world (Photo 3).
\end{abstract}

Keywords: Poland, touristic visits, foreign tourists

\section{WSTĘP}

Samo pojęcie terminu turystyka zagraniczna jest tworem stosunkowo młodym, natomiast tradycja wyjazdów Polaków za granicę liczy już kilka wieków. Ciekawie ujmuje to Schulz (1956) mówiąc: „Francja od najdawniejszych czasów była ulubionym dla Polaków krajem", albo pociągają ich ku sobie Szwajcaria i Włochy, jako że „sama natura tych obu krajów tak jest różną od polskiej z najrozmaitszych względów, że ona sama jest już źródłem wielkich przyjemności”. „Najczęściej spotkać ich można w Wenecji, Rzymie, Neapolu, Florencji, gdzie [...] - zatrzymywać się zwykli dłużej”. Dalej pisze Schulz: „Najoryginalniejszym [...] jest hrabia Jan Potocki. Długi bardzo przeciąg czasu spędził w różnych krajach Europy, we Francji, Włoszech Anglii i Hiszpanii [...], zwiedził on Turcję, Arabię, Syrię i znaczną część Persji”".

Mówiąc o turystyce zagranicznej w Polsce, rozumiemy oczywiście jej rozwój 
dwustronny, tzn. wyjazdy obywateli polskich, jak również przyjazdy gości zagranicznych o charakterze turystycznym do naszego kraju.

\section{POCZĄTKI TURYSTYKI ZAGRANICZNEJ W POLSCE}

Według Warszyńskiej i Jackowskiego (1978) dla międzynarodowej turystyki przyjazdowej do Polski znaczący był rok 1929, chociaż w porównaniu z innymi krajami niezbyt okazały. Nasz kraj bowiem odwiedziło wówczas 176000 turystów, gdy na przykład do Wielkiej Brytanii przyjechało w celach turystycznych 409 tys. osób, do Włoch 1221 tys., do Francji 1911 tys. Do Szwajcarii przybyło 2480 tys. turystów. Oznacza to, że przez okres międzywojenny Polska nie należała do krajów zbyt często odwiedzanych przez cudzoziemców. Również udział Polaków w międzynarodowej turystyce wyjazdowej, w porównaniu chociażby z obywatelami krajów Europy Zachodniej, był stosunkowo niewielki.

Z powodów politycznych również w latach 1945-1955,1956, niemal nie istniała turystyka zagraniczna (Kulczycki 1968). Właściwie dopiero pod koniec wymienionego okresu możemy mówić o istnieniu u nas turystyki zagranicznej. Za jeden z jej przejawów można uznać umowę Polski z Czechosłowacją o ruchu

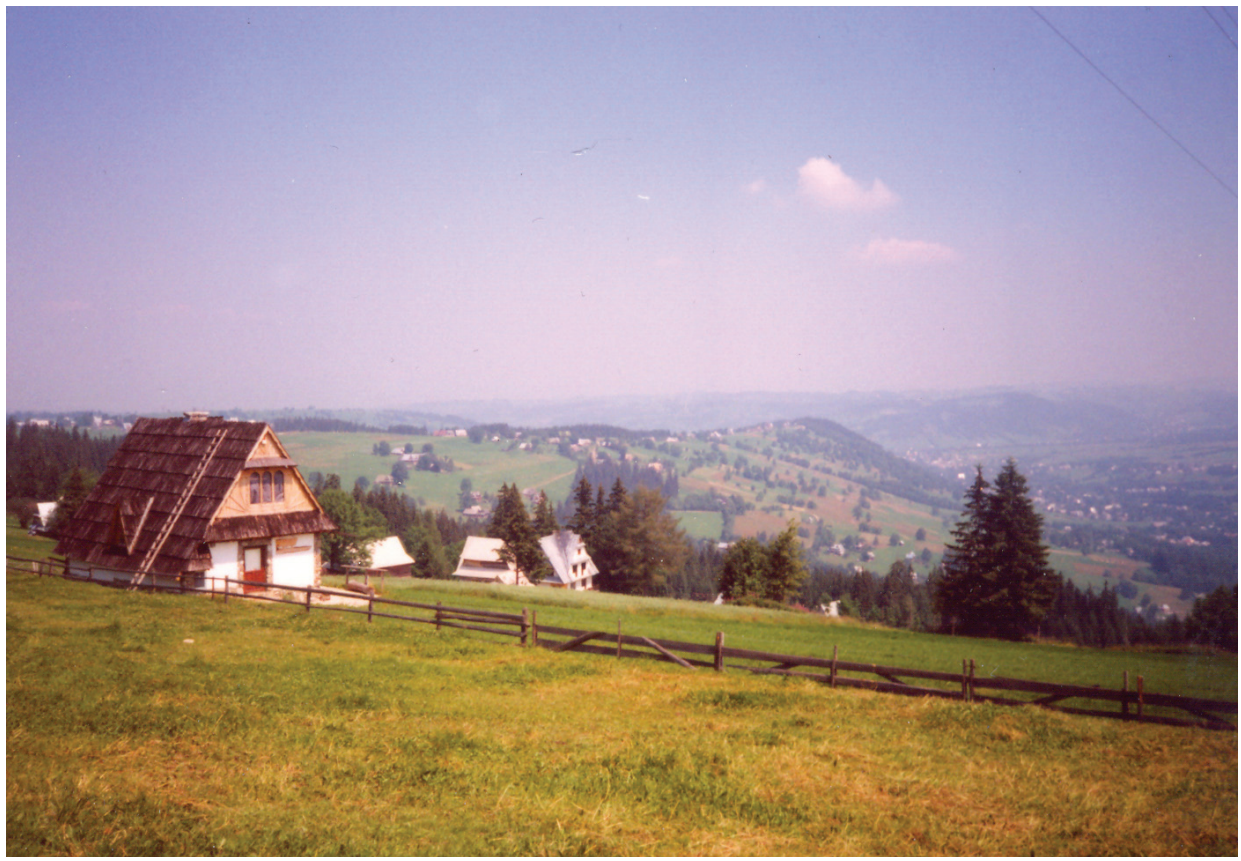

Fot. 1. Tatry - Gubałówka

Photo 1. The Tatra Mountains - Gubałówka 
turystycznym w rejonie Tatr. Zgodnie z Rocznikiem Politycznym i Gospodar$c z y m \mathrm{z}$ roku $1958 \mathrm{w}$ ramach tej umowy pod koniec lat 50. ubiegłego wieku 84000 turystów polskich odbyło wycieczki w Tatry Słowackie, 52000 turystów czeskich zaś odwiedziło Zakopane i okolice (fot. 1).

Pewne znaczniejsze ożywienie zagranicznego ruchu turystycznego nastąpiło w roku 1960. Według danych ówczesnego Ministerstwa Spraw Wewnętrznych (zob. Mały rocznik statystyczny, 1971) z naszego kraju wyjechało wówczas 216,4 tys. turystów, w tym 175,0 tys. do tzw. krajów socjalistycznych i 41.4 tys. do innych państw. Przyjechało zaś 184 tys. turystów zagranicznych, w tym 130 tys. z krajów obozu socjalistycznego i 54 tys. z krajów pozostałych.

Pięć lat później obserwujemy już wyraźniejszą dynamikę wzrostu ruchu turystycznego w Polsce. I tak, w roku 1965 z kraju wyjechało 778,4 tys. turystów, w tym 702,7 tys. do krajów socjalistycznych i 75,7 tys. do innych państw. Do Polski przybyło natomiast 1162,900 osób - 972,8 z krajów socjalistycznych oraz 190,1 z pozostałych krajów.

Ujmując ogólnie można powiedzieć, że zagraniczny ruch turystyczny w Polsce, w latach 50. i 60. był dosyć ograniczony. Odbywał się głównie w ramach wymiany z krajami tzw. Rady Wzajemnej Pomocy Gospodarczej (RWPG).

Szerszy rozwój ruchu turystycznego, łącznie z udziałem państw zachodnich, nastąpił dopiero w latach 70. ubiegłego stulecia. W roku 1970 liczba turystów odwiedzających Polskę wynosiła już 1889,000, a z kraju wyjechało 871,000 osób. Szczególnie szybki wzrost zagranicznego ruchu turystycznego miał miejsce w latach 1972-1980. W znacznej mierze był on spowodowany zniesieniem obowiązku posiadania paszportu w wymianie zagranicznej z NRD, a później także z Czechosłowacją.

\section{ORGANIZACJE ZAJMUJĄCE SIE ZAGRANICZNYM RUCHEM TURYSTYCZNYM W POLSCE PO II WOJNIE ŚWIATOWEJ}

Po II wojnie światowej tworzeniem i rozwojem zagranicznego ruchu turystycznego w Polsce zajmowało się szereg organizacji społecznych i politycznych, przy których utworzono biura podróży. Głównym organizatorem tego ruchu było Polskie Biuro Podróży „Orbis”. Poza nim zagranicznym ruchem turystycznym zajmowało się:

- Polskie Towarzystwo Turystyczno-Krajoznawcze (Biuro Wymiany Międzynarodowej),

- Związek Młodzieży Socjalistycznej (Biuro Zagranicznej Turystyki Młodzieży „Juventur”),

- Zrzeszenie Studentów Polskich (Biuro Wczasów, Podróży i Turystyki),

- Polski Związek Motorowy (Biuro Turystyki Motorowej), 
- Polski Komitet Olimpijski (Sport-Tourist),

- Biuro Wczasów i Turystyki Związku Nauczycielstwa Polskiego,

- Spółdzielnia Turystyczno-Wypoczynkowa „Turysta”,

- Ogólnokrajowa Spółdzielnia Turystyczno-Wypoczynkowa „Gromada”,

- z Biurem Turystyki Zagranicznej (BTZ).

\section{PBP,ORBIS” - JEGO ROLA W TURYSTYCE ZAGRANICZNEJ}

Powiedziano już, że po II wojnie światowej (na przełomie lat 50. i 60. ubiegłego stulecia) w organizacji zagranicznego ruchu turystycznego w Polsce najpoważniejszą rolę odgrywało Polskie Biuro Podróży „Orbis”. Można powiedzieć, że było to znaczące przedsiębiorstwo, którego liczba korespondentów w roku 1961 obejmowała około 300 zagranicznych biur podróży z całego świata. Jego oferta była dosyć bogata. Obejmowała m.in.: sprzedaż biletów komunikacji krajowej i międzynarodowej (bilety kolejowe, lotnicze, autobusowe, okrętowe, promowe), sprzedaż wycieczek zagranicznych, organizację indywidualnych wyjazdów turystycznych.

Spójrzmy jak wyglądała, w poszczególnych latach, statystyka zagranicznego ruchu turystycznego organizowanego przez PBP „Orbis” (zob. Kłysz 1963).

W roku 1958 „Orbis” obsłużył 41500 turystów zagranicznych i 13 tys. turystów polskich. Rok 1959 to obsługa 57000 turystów zagranicznych i 21 tys. turystów polskich.

Poważny wzrost usług świadczonych przez „Orbis” notujemy w roku 1960. W roku tym Polskę, za jego pośrednictwem, odwiedziło około 100 tys. turystów zagranicznych. Za granicę wyjechało zaś 24 tys. turystów polskich. Można zaznaczyć, że wartość świadczonych w tym okresie usług, w porównaniu z rokiem 1959, wzrosła o około $30 \%$.

W roku 1961 „Orbis” był już na tyle zorganizowany, szczególnie w zakresie przygotowania bazy turystycznej, że w sezonie mógł praktycznie biorąc, przyjąć każdą liczbę turystów, zarówno grupowych, jak i indywidualnych. Niejako odzwierciedleniem tego był fakt, że przedsiębiorstwo obsłużyło około 150 tys. turystów z 75 krajów.

Wśród klientów „Orbisu” w roku 1961 przeważali turyści z krajów Europy Zachodniej i krajów zamorskich. Przybyło ich do nas ponad 90 tys., w tym z Francji przyjechało prawie 11 tys., z Anglii prawie 10 tys. osób. Niemal 9 tys. klientów miał „Orbis” z NRF. Około 20 tys. chętnych poznania naszego kraju przybyło z USA i Kanady. Stosunkowo pokaźną grupę stanowili turyści czechosłowaccy, których przybyło do Polski około 15 tys. Polskę odwiedziło także około 7 tys. turystów z ZSRR.

Jeśli chodzi o turystów polskich, to w roku 1961, za pośrednictwem „Or- 
bisu", do 45 krajów wyjechało ponad 30 tys. osób. Największym powodzeniem cieszyły się wycieczki do ZSRR, w których brało udział ponad 7,5 tys. osób. Do Czechosłowacji wyjechało około 6 tys. turystów, do Bułgarii 4 tys. i do Włoch około 1,5 tys. osób. Wysoką frekwencję miały również turystyczne rejsy statkami do portów śródziemnomorskich (zob. „Podróże i Turystyka” nr 2/1961, 1, 3/1962).

Według wskazanego wyżej informatora („Podróże i Turystyka” nr 10/1962) dla turystów, którzy zamierzali przyjechać do Polski nie indywidualnie, lecz w grupach „Orbis” oferował w roku 1962 dziewiętnaście tras po kraju. W roku następnym proponowano już 36 różnorodnych programów wycieczek. Trasy wycieczek zostały tak ułożone, aby umożliwić poznanie, w ciągu stosunkowo krótkiego czasu, najciekawszych regionów naszego kraju.

Przykładowo: 12-dniowa wycieczka „Wokół Polski”. Proponowana trasa prowadziła - z Warszawy przez: Puławy - Kazimierz Dolny - Lublin - Sandomierz - Rzeszów - Łańcut - Kraków - Zakopane - Oświęcim - Częstochowę - Opole - Wrocław - Kalisz - Poznań - Gniezno - Kruszwicę - Torun - Włocławek - Żelazową Wolę z powrotem do Warszawy.

Również z Warszawy rozpoczynały się i kończyły nieco krótsze wycieczki - 9-dniowe. Każda z nich obejmowała jeden z regionów Polski. Można tu wymienić takie wycieczki, jak:

- „Polska Północna” prowadząca przez Pojezierze Mazurskie,

- „Polska Południowa, której trasa wiodła przez Podhale i Tatry,

- „Polska Południowo-Zachodnia” podczas której turyści mogli zwiedzić Wielkopolskę i Śląsk,

- „Polska Północno-Zachodnia” obejmująca ziemie nadmorskie wzdłuż wybrzeża Bałtyku,

- „Polska Zachodnia” rejony nad Odrą i Nysą Łużycką.

Przygotowano także inne ciekawe trasy. Ich programy dostosowano do określonych zainteresowań uczestników. Mówią o tym już same nazwy wycieczek, na przykład: „Folklor Polski”, „Flora i fauna Polski Południowej”, „Flora i fauna Polski Północnej”, „Architektura Polski”. Wycieczki te trwały od 10 do 13 dni.

Dla szczególnych miłośników folkloru i autentycznej samorodnej sztuki ludowej przygotowana była specjalna wycieczka 10-dniowa z Warszawy przez: Kadzidło - Opoczno - Kielce - Łysą Górę - Kraków - Zakopane - Szczawnicę - Żywiec - Koniaków - Istebną - Katowice - Łowicz.

Przy organizacji wycieczek zbiorowych do Polski w 1963 roku szczególnym ułatwieniem było przyjęcie przez „Orbis” zasady, że grupa turystyczna rozpoczyna się od 10 osób, a nie od 15 , jak było dotychczas. Umożliwiało to zagranicznym biurom podróży i organizacjom organizowanie wycieczek nawet wówczas, jeśli nie udało się zebrać, w określonym czasie, większej liczby uczestników. 
Na uwagę zasługiwało również wprowadzenie 10-procentowej zniżki cen dla wycieczek odbywających się poza sezonem. Jako sezon, na terenie całej Polski, rozumiany był okres od 1 czerwca do 30 września. Jedynie w Zakopanem jeszcze dodatkowo obowiązywał okres turystyczny od 20 grudnia do 31 marca.

Oprócz wymienionych wycieczek „Orbis” przygotował dla turystów zagranicznych 10-12-dniowe pobyty wypoczynkowe w najpiękniejszych miejscowościach uzdrowiskowych i wypoczynkowych Polski.

Poza programami wycieczek dla grup turystycznych przygotowano także szereg atrakcyjnych wycieczek autokarowych do najciekawszych regionów Polski dla turystów przybywających do nas indywidualnie.

Jak donosiła ówczesna prasa (zob.: „Trybuna Ludu” 26.09.1962 r.), interesujące oferty zaplanował „Orbis” również dla turystów polskich. Przewidziano między innymi letnie pobyty wypoczynkowe w górskich miejscowościach Czechosłowacji, a w sezonie zimowym 2-tygodniowe wyjazdy do tego kraju, na narty.

Dalsze możliwości dla polskiej turystyki wyjazdowej stwarzała umowa podpisana 15.12.1962 r. w Berlinie przez przedstawicieli „Orbisu” i „Deutsches Reisebüro", otwierająca z 1 stycznia 1963 r. konwencję turystyczną, wówczas z byłą Niemiecką Republiką Demokratyczną (NRD). Turystom polskim udostępniono trzy okręgi:

- drezdeński i Cottbus, do których prowadziło przejście graniczne w Zgorzelcu oraz

- Neubrandenburg z przejściem w Kołbaskowie koło Szczecina.

Niewątpliwą atrakcją turystyczną, przygotowaną także przez „Orbis” (w przekazie cytowanej już prasy) był dwutygodniowy pobyt w Mongolii, połączony z polowaniami. Planowana była również wycieczka do Japonii. W tej wersji początkowo trasa wiodła samolotem z Warszawy do Władywostoku. W jej ofercie przewidziane było również zwiedzanie Moskwy, Irkucka w ZSRR, Ułan Bator w Mongolii i dalej już statkiem do Japonii.

\section{POLSKA W OPINII TURYSTÓW ZAGRANICZNYCH}

Chociaż Polska, z upływem lat, stawała się krajem coraz chętniej odwiedzanym przez turystów, podkreślano, że tendencja ta może się zmieniać i to niezbyt korzystnie. Przyczynę ma stanowić standard usług, który ma być u nas o wiele niższy niż w innych krajach, głównie europejskich. Jak podaje Barlik (1993) turyści zagraniczni, szczególnie lat 80 . ubiegłego stulecia, często mieli krytykować w Polsce: wysokie koszty pobytu (32,5\% ankietowanych), trudny dojazd $(13,7 \%)$, stan sanitarny $(12,6 \%)$, system informacji turystycznej

$(11,4 \%)$, poziom świadczonych usług $(9,8 \%)$, organizację przyjazdu $(8,9 \%)$. 
Ogólnie - 2,2\% proszonych o opinię uważało, że Polska jest krajem mało atrakcyjnym turystycznie.

Zupełnie inne odczucia wynoszą z Polski turyści odwiedzający nasz kraj nieco wcześniej, chociażby w latach 60. ubiegłego wieku. Istniała wówczas, właściwie jednomyślna, opinia, że Polska posiada wspaniałe walory turystyczne! Przeważnie były one odkrywane dopiero na miejscu. Podkreślano między innymi, że jest ona jednym z nielicznych krajów w Europie, w których zachowały się jeszcze, nietknięte zmianami cywilizacyjnymi, znaczne połacie pierwotnej przyrody.

W Biuletynie PBP „Orbis” nr 10 - „Podróże i Turystyka” z roku 1962 czytamy, że cudzoziemcy znajdują w naszym kraju wszystko, czego można oczekiwać po wędrówce turystycznej. Wymieniają tu piękną zabytkową architekturę (fot. 2), w wielu okolicach, jak już powiedziano, pierwotną nieskażoną cywilizacją przyrodę. Podkreślają, że obok modnych luksusowych kurortów można znaleźć odosobnione kwatery w zacisznych leśniczówkach czy położonych na uboczu uczęszczanych szlaków schroniskach. Obok starodawnych oryginalnych obyczajów ludowych podziwiać tu można najbardziej nowoczesną technikę.

Właśnie ta różnorodność i bogactwo form życia mają stanowić główną atrakcję naszego kraju. Uwagę zwraca ponadto, powszechnie podkreślana, gościnność

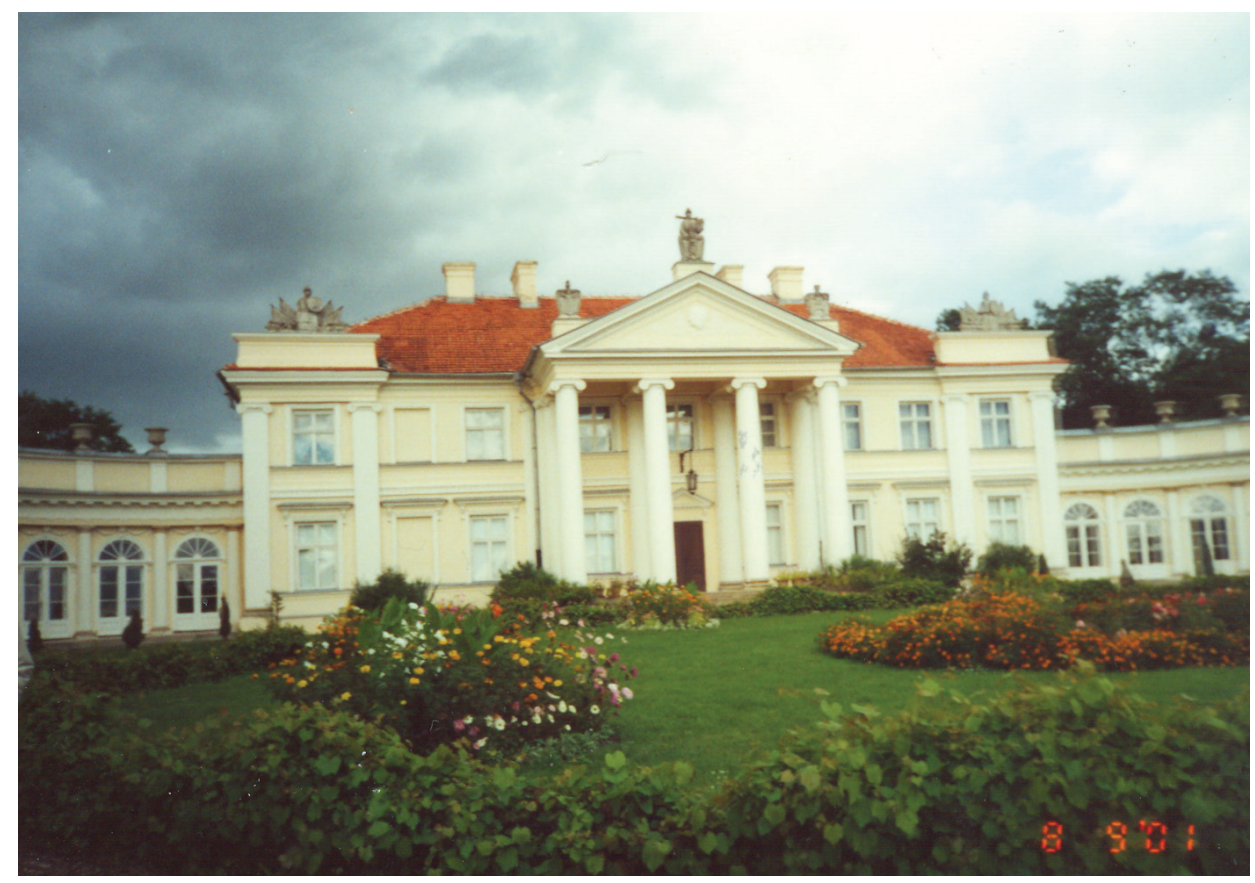

Fot. 2. Pałac w Śmiełowie (SE Wielkopolska)

Photo 2. The palace in Śmiełów (SE Great Poland) 
i życzliwość Polaków. O prawdziwości powyższych opinii świadczyć mogą wypowiedzi osób, które odwiedzily nasz kraj. Znajdujemy je we wskazanym już biuletynie „Podróże i Turystyka” z lat 1961, 1962. Czytamy tu m.in.:

Jestem zupełnie oczarowany Polską [stwierdza prof. David Ericson z Obserwatorium Geologicznego Uniwersytetu Columbia]. Gdybym mógł rok mieszkać w Warszawie byłbym szczęśliwy. Śliczny jest polski pejzaż. Spokój płynący z widoku kolorowych pól i łąk działa kojąco.

Oto co pisze p. Gert Hindemar ze Szwecji:

Dwa dni temu wróciłem do domu po dziesięciodniowej podróży po Polsce [...] Pragnę Wam podziękować za doskonałą organizację tej podróży i za wszystko co Wasi przewodnicy pokazali mi i powiedzieli. Jestem bardzo zadowolony z wszystkiego: hoteli, jedzenia, wycieczek i przewodników.

W tej krótkiej relacji posłuchajmy p. Rogera Vincenta, członka FIJET, Sekretarza Generalnego Agencji Prasowej „Liaison et Diffusion”. Mówi on:

Pragnę wyrazić moje najszczersze podziękowanie za miły pobyt w Polsce. Dzięki Waszej dobrej organizacji mogliśmy zwiedzić maksimum obiektów w czasie bardzo ograniczonym, za to w najlepszych warunkach.

Moja żona i ja zachowaliśmy jak najlepsze wspomnienia z tej podróży i mamy nadzieję powrócić znowu do Waszej Ojczyzny.

Wymienione lata to równocześnie okres wzmożonych wyjazdów turystycznych naszych rodaków w miejsca, które nie cieszyły się dotychczas większą renomą. Takim szczególnym obszarem stała się, wymieniona już, Jugosławia. Jak podawał Przewodnik gospodarczy tego kraju z roku 1958, dwa lata wcześniej (1956) Jugosławii nie odwiedził żaden turysta polski. Już rok następny (1957) zamknął się cyfrą 9688 turystów, którzy udali się tam, aby podziwiać uroki Doliny Logarskiej, jezior Plitwickich, Bledu, Hwaru.

Nasi turyści docierali także do wielu innych, atrakcyjnych turystycznie, rejonów naszego globu. Na fotografii 3 widzimy podziwiany przez rodaków fiord Lustra stanowiący jedną z odnóg najdłuższego na kuli ziemskiej fiordu Sogne, położonego na zachodnim wybrzeżu Norwegii. Takich miejsc i rejonów można byłoby wskazać znacznie więcej.

\section{UWAGI KOŃCOWE}

Znacząco różniła się w wartościach liczbowych ówczesna polska turystyka zagraniczna od turystyki dzisiejszej. Na podstawie przedstawionych danych zawartych w Matym Roczniku Statystycznym 1971 powiedziano, że w roku 1960 do Polski przyjechało 184 tys. turystów, wyjechało zaś 216,4 tys. osób. Obecnie 


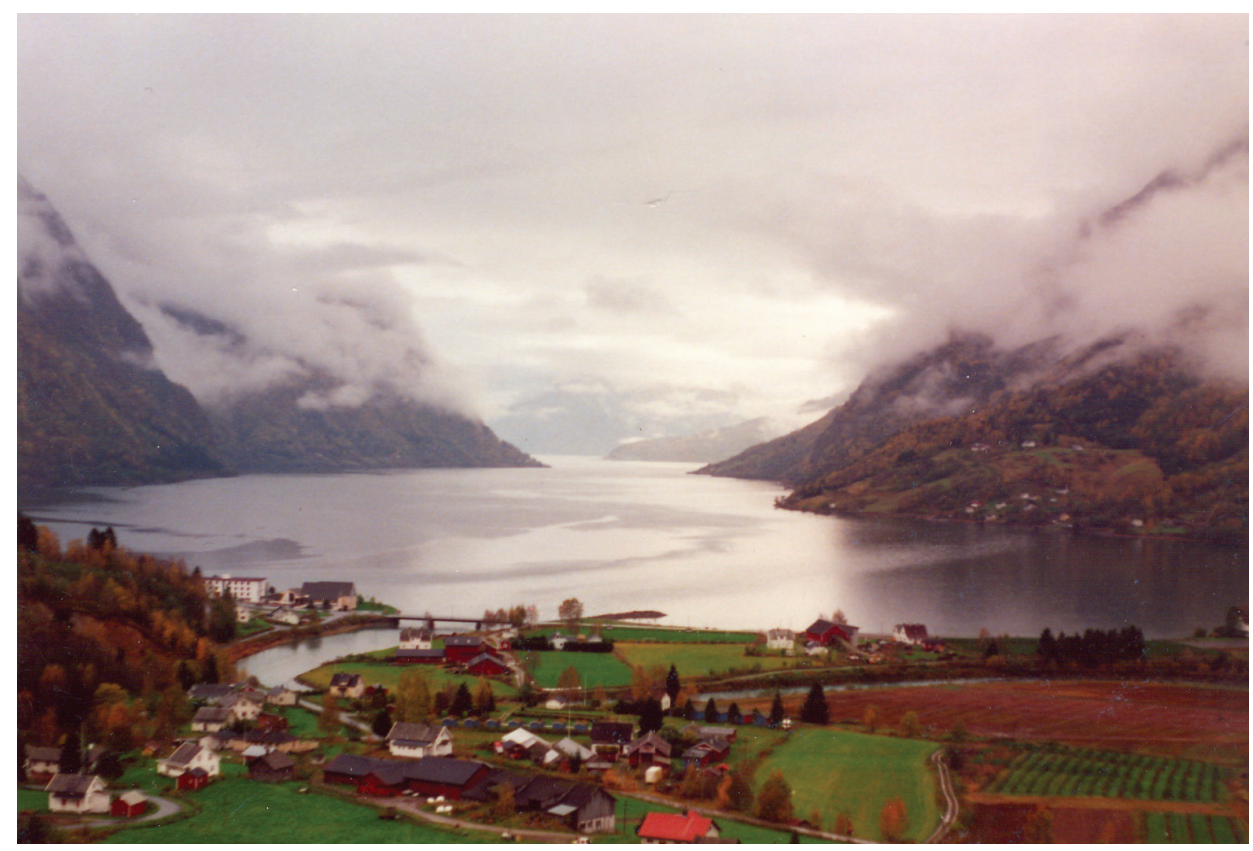

Fot. 3. Odgałęzienie Sognefjordu - Lustrafjord. Widok ze Skjolden (Norwegia)

(fot. J. Długosz)

Photo 3. The branching of Sognefjord - Lustrafjord. A view from Skjolden (Norway)

(Photo by J. Długosz)

według danych Instytutu Turystyki w roku 2008 nasz kraj odwiedziło $13 \mathrm{mln}$ turystów, wyjechało 7,1 mln naszych rodaków. Jest to oczywiście znaczący wzrost zagranicznego ruchu turystycznego, ale mając na uwadze dystans czasowy, nie powinno to rodzić zdziwienia. Wydaje się, że nie jest to pułap optymalny rozwoju polskiej turystyki zagranicznej, zwłaszcza wyjazdowej. Na jej obecny stan z pewnością wpływa nie najlepsza aktualnie sytuacja ekonomiczna kraju.

Bazując na doniesieniach prasowych, pewnym ogranicznikiem może być także wiarygodność niektórych biur podróży. Czytamy bowiem m.in.:

Turyści, którzy wykupili już wczasy [...] z niepokojem patrzą w kalendarz, obawiając się, czy przypadkiem nie upadnie ich biuro podróży” („Polska Głos Wielkopolski" z 28 lipca 2009).

Kolejny czynnik wpływającym hamująco na rozwój zagranicznego ruchu turystycznego to niewątpliwie nasilający się w ostatnim czasie terroryzm. Prasa sierpniowa z roku 2009 donosi np.:

Władze Majorki obawiają się, że turyści mogą zacząć masowo rezygnować z wakacyjnych przyjazdów na wyspę (dodajmy ulubione miejsce wczasowo-turystyczne Polaków). 


\section{I dalej:}

Turystów zawiadomiono, że zwiększy się jeszcze bardziej środki bezpieczeństwa na Majorce, co ma przeciwdziałać kolejnym zamachom bombowym (zob.: „Polska Głos Wielkopolski” z 12 sierpnia 2009).

\section{LITERATURA}

Barlik E., 1993: Zajazdy, hotele turystyczne, Hiltony... Rzeczpospolita, nr 15(3359), 19 I 1993, dodatek - Ekonomia i Rynek, II.

Kłysz P., 1963: Zagraniczny ruch turystyczny w Polsce w latach 1956-1962. Gorzów Wlkp. [maszynopis].

Kowalczyk A., 2002: Geografia turyzmu. Wyd. Nauk. PWN, Warszawa.

Kulczycki Z., 1968: Zarys historii turystyki w Polsce. Sport i Turystyka, Warszawa.

Lijewski T., Mikułowski B., Wyrzykowski J., 2002: Geografia turystyki Polski. Polskie Wyd. Ekonomiczne, Warszawa.

Schulz F., 1956: Podróże Inflantczyka, wyd. I. Czytelnik, Warszawa.

Warszyńska J., Jackowski A., 1978: Podstawy geografii turyzmu. PWN, Warszawa.

\section{MATERIAŁY INNE}

Jugosławia - Przewodnik Gospodarczy, 1958. Wyd. Privredni Pregled, Belgrad.

Podróże i Turystyka - Biuletyn PBP „Orbis”:10/61, 10/62, 11/62.

Podróżuj z „Gromadą”. Zakł. Wyd. CRS, Warszawa, 1970.

Rocznik polityczny i gospodarczy, 1958, 1959, 1960.

Rocznik statystyczny, 1961, 1977. GUS, Warszawa.

Maty rocznik statystyczny, 1971. GUS, Warszawa.

„Sztandar Młodych” 25.10.1962.

„Trybuna Ludu” nr 266/4935 - 26.09.1962.

„Polska Głos Wielkopolski” - 28.07.2009, 12.08.2009. 